\title{
Saving Imbalances and the Euro Area Sovereign Debt Crisis
}

\author{
Matthew Higgins and Thomas Klitgaard
}

For several years prior to 2010, countries in the euro area periphery engaged in heavy borrowing from foreign private investors, allowing domestic spending to outpace incomes. Now these countries face debt crises reflecting a loss of investor confidence in the sustainability of their finances. The result has been an abrupt halt in private foreign lending to these economies. This study explains how the periphery countries became dependent on foreign borrowing and considers the challenges they face reigniting growth while adjusting to greatly reduced access to foreign capital.

$\mathrm{T}$ he sovereign debt crisis in the euro area is ongoing and proving difficult to resolve. The crisis turned acute in early 2010 when yields on Greek government debt spiked amid growing market doubts about the sustainability of the country's finances. Borrowing rates soon became prohibitively high for other fiscally troubled countries in the euro area periphery, such as Ireland and Portugal. All three countries have been forced to seek financial support from the International Monetary Fund (IMF) and the European Union to make up for lost support from private investors. The question still being debated is how these debts will be paid back over time.

The countries most affected by the euro area sovereign debt crisis had engaged in substantial foreign borrowing for a number of years. The turn to foreign borrowing was facilitated by entry into the European Economic and Monetary Union. Before the late 1990s, countries in the euro area periphery faced much higher interest rates than did euro area core countries, such as Germany. However, once the periphery countries joined the monetary union, the interest rates they paid fell sharply as market participants judged that the value of investments in these countries would no longer be vulnerable to erosion through currency depreciation. Low interest rates, however, spurred heavy foreign borrowing by both the public and private sectors in the countries now facing debt crises. The problem is that foreign capital was used to support domestic consumption or housing booms rather than productivityenhancing investments.

Adjustment efforts in countries affected by the sovereign debt crisis have mostly focused on engineering quick reductions in fiscal deficits. But the more fundamental adjustment will require sharply reduced foreign borrowing, with spending in the economy falling back in line with national income. Before joining the monetary union, the periphery countries could have relied on a weaker currency to boost exports and support growth while undertaking this difficult adjustment. With the exchange rate no longer available as an adjustment mechanism, the challenge now is how best to lower domestic spending while sustaining growth. In this edition of Current Issues, we explain how the periphery countries became dependent on foreign borrowing and consider the problems they face reigniting economic growth while adjusting to sharply reduced access to foreign capital. 


\section{Chart 1 \\ Ten-Year Government Bond Spreads to German Equivalent}

Sovereign Interest Rate - German Interest Rate

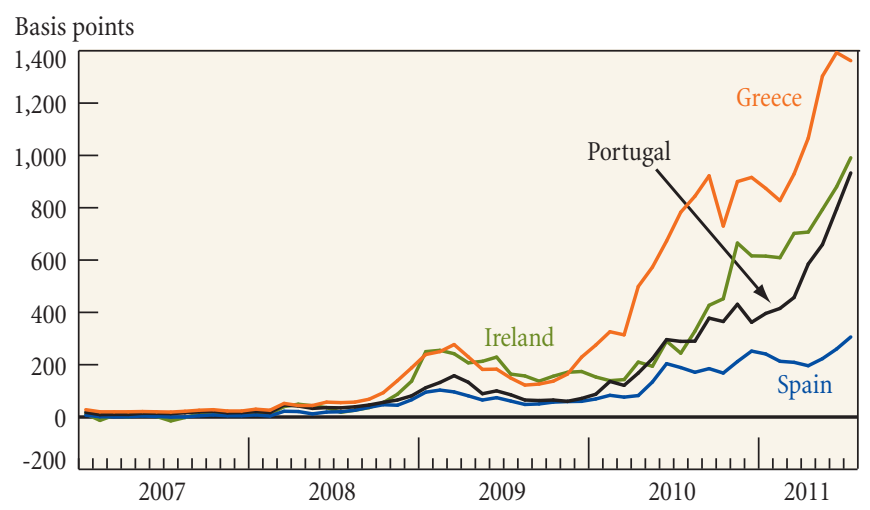

Sources: National central banks; Financial Times; Haver Analytics.

Note: Data are through July 2011.

\section{The Euro Area Sovereign Debt Crisis}

The countries hit hardest by the 2010 euro area sovereign debt crisis had run large current account deficits for several years. The crisis took hold in early 2010 when the incoming Greek government announced that the fiscal budget deficit for 2009 was far larger than previously estimated. This large deficit restatement raised concerns about the sustainability of Greece's fiscal position. Markets responded by demanding much higher yields on Greek debt. This set off a vicious cycle, with the increase in debt service costs further undermining the government's fiscal position. Concerns over fiscal sustainability soon set off a similar dynamic in Ireland, Portugal, and, to a much lesser extent, Spain.

The magnitude of the market's reassessment of credit risk can be seen in the spread between ten-year government bond yields in the euro area periphery countries and in Germany (Chart 1). In 2007, the spreads hovered close to 25 basis points, suggesting that investors saw little difference in credit risk between Greek and German bonds. The spread for Greek bonds climbed past 150 basis points in late 2008, with the global financial crisis making investors leery of all but the safest credit risks. The spread then shot up dramatically after the Greek government's deficit restatement, climbing to more than 800 basis points in June 2010 despite the May announcement of a support package from the IMF and European Union that covered the Greek government's expected funding needs through 2011. By July 2011, the spread was more than 1,300 basis points. Irish and Portuguese yields also moved higher during the second half of 2010 and the first half of 2011, exceeding 900 basis points in July. Spain remains in a much better position, with its spread close to 300 basis points.

In response to these market pressures, the periphery countries have been forced to commit to painful fiscal austerity measures.
Greece has agreed to undertake the most severe consolidation efforts, summing to almost 25 percent of GDP over the 2010-14 period. Ireland has committed to implement consolidation measures totaling 18 percent of GDP by 2014, and Portugal to measures totaling more than 12 percent of GDP. Spain, which has not had to seek external assistance, plans to implement measures totaling roughly 8.5 percent of GDP. These measures are projected to bring fiscal deficits to below 3 percent of GDP by 2013 in Portugal and Spain and by 2015 in Greece and Ireland.

There are important differences among the euro area periphery countries as to how fiscal vulnerabilities developed. Portugal, like Greece, was running a sizable fiscal deficit even before the recent recession. Ireland and Spain, in contrast, had strong fiscal positions before the downturn. However, both countries had massive real estate bubbles and credit-fueled construction booms. The loss in tax revenues when the bubbles popped and booms turned to busts was particularly dramatic. Moreover, governments in both countries (especially Ireland) face large actual and potential costs from supporting their ailing banking sectors.

These countries all relied on cheap foreign borrowing to support growth in the years leading up to the debt crisis. The question going forward is how they will adjust to the loss of market access and private investment inflows.

\section{Borrowing and Lending by Countries}

A country's saving balance is equal to the difference between domestic saving and domestic investment spending. A country that saves more than is needed to support domestic capital expenditures sends the surplus abroad to purchase foreign assets. Conversely, a country where domestic saving is insufficient to finance domestic capital expenditures must borrow from abroad to make up the shortfall. As an accounting identity, a country's saving balance is equal to its current account balance, that is, the trade balance broadly construed:

\section{current account balance $=$ domestic saving - domestic investment spending.}

After all, a country that saves more than it invests also produces more than it consumes. Through cross-border lending and borrowing, countries with surpluses build up a store of foreign wealth while countries with deficits are able to maintain higher levels of consumption and investment spending than would be possible without foreign financing.

Saving imbalances in the euro area have recently been quite large. In the 2007 run-up to the global financial crisis, Greece, Portugal, and Spain had saving deficits of 10 to 15 percent of GDP, the largest in the euro area (Chart 2). Ireland had a much smaller but still substantial deficit of around 5 percent of GDP. Germany, in contrast, had a surplus of roughly 8 percent of GDP.

The seeds of these imbalances were planted by the creation of a common currency area. The euro area periphery countries had 
Chart 2

\section{Saving Balances as a Share of GDP}

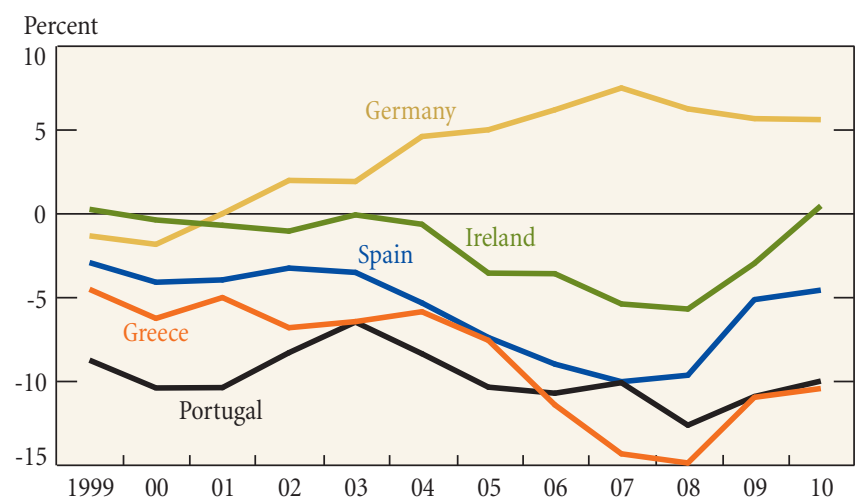

Sources: Eurostat; Haver Analytics.

Note: Saving balances are measured by the current account.

a history of relatively high inflation, especially compared with Germany. Normally, countries with such a record are required by investors to pay an interest rate premium to compensate for the risk of being repaid a nominal sum that has diminished real purchasing power. This point can also be made from an exchange rate perspective. Currencies of high-inflation countries are strongly prone to depreciation (if the currency is flexible against other currencies) or devaluation (if it is fixed but adjustable against other currencies). Thus, before the advent of the euro, a German investor might be repaid in Greek drachma worth fewer deutsche marks, thus requiring higher Greek interest rates as compensation.

After the creation of the euro area, Greece and other periphery countries had access to financing at much lower interest rates than would otherwise have been possible (Chart 3). Investors knew that monetary policy for the region as a whole would be set by the European Central Bank (ECB), seen as likely to continue the strong anti-inflation policies of Germany's central bank. This essentially eliminated the risk that investments in periphery countries' debt instruments would be eroded by high inflation. Moreover, given the common currency, the possibility of depreciation or devaluation in the periphery countries was eliminated as well. The one risk that remained, of course, was credit or default risk: the prospect that the periphery sovereigns could not or would not make good on obligations as they came due-something to which the market assigned little probability. ${ }^{1}$

Not surprisingly, the fall in interest rates that came with the periphery countries' entry into the euro area facilitated the buildup of current account deficits. Lower interest rates spurred investment spending, as more projects had expected returns

\footnotetext{
${ }^{1}$ The spread between borrowing rates of euro area periphery countries and Germany would also incorporate a liquidity premium, reflecting the ease of deal-making in the large German debt market.
}

Chart 3

\section{Ten-Year Government Bond Yields, 1990-2000}

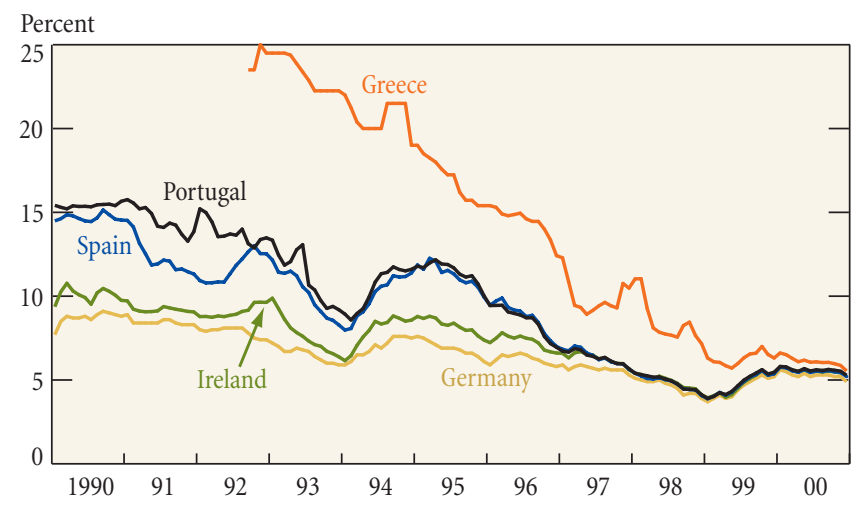

Sources: National central banks; Financial Times; Haver Analytics.

above the cost of borrowing. ${ }^{2}$ Lower rates also meant that governments would pay less to investors for additional borrowing. The impact of interest rates on personal saving is theoretically ambiguous, although most empirical studies find that lower rates reduce saving. ${ }^{3}$

In retrospect, investors misjudged the risks of lending to euro area periphery countries at paper-thin spreads over rates in Germany. Indeed, the high current account deficits in the euro area periphery would likely have prompted investors to reassess the fundamental creditworthiness of those countries much earlier if not for the reassurance provided by their membership in the monetary union. However, the periphery country economies now face the prospect of diminished market access and the need to sharply reduce external borrowing. The May 2011 edition of the Organisation for Economic Co-operation and Development's (OECD) Economic Outlook predicts that periphery countries' current account deficits will narrow by an average of roughly 7.5 percentage points relative to GDP over the 2007-12 period.

That said, the decline in periphery countries' current account deficits thus far has been much more limited than the pullback in private capital inflows. According to data from the International Monetary Fund, private foreign investment in Greece, Portugal, and Spain came to some $€ 338$ billion in 2007. In the four most recent quarters with available data (through first-quarter 2011),

\footnotetext{
${ }^{2}$ Investment demand and saving supply depend on real, or inflation-adjusted, interest rates, rather than nominal interest rates, a distinction we do not make here for the sake of brevity. After the creation of the euro area, real interest rates in the periphery countries declined sharply and by far more than real interest rates in Germany. For example, comparing the 1994-98 and 2003-07 periods, we note that real long-term government bond yields declined by 235 basis points in Germany, but by 370-565 basis points in the four periphery countries. The behavior of current account balances and real interest rates in the euro area is consistent with the predictions of simple textbook models, in which closer financial integration leads to capital flows from initially low-interest-rate to initially high-interest-rate countries.

${ }^{3}$ See Attanasio and Weber (2010) for a literature review.
} 
private capital inflows dropped to -€88 billion, reflecting liquidation of existing investments - a turnaround equivalent to almost one-third of the countries' combined GDP. (Including Ireland, with its large banking sector, would roughly double private inflows in 2007, while slightly boosting liquidations in the four recent quarters.) Yet the drop in the three countries' combined current account deficits over the period came to less than 5 percent of GDP.

Three factors explain this mismatch. First, the periphery countries themselves have pulled back from making new foreign investments, instead selling off existing assets to free up funds to pay off external creditors. In 2007, Greece, Portugal, and Spain invested $€ 219$ billion abroad; however, in the four quarters through first-quarter 2011, the figure had fallen to - $€ 65$ billion. ${ }^{4}$ Second, official adjustment assistance has replaced some of the sudden halt in private inflows. Greece received $€ 32$ billion in financing from the IMF and European Union last year, and Greece, Ireland, and Portugal are expected to receive a total of more than $€ 90$ billion this year. Finally, some of the periphery countries' current account deficits have been indirectly financed by credit from central banks in euro area core countries. By March 2011, periphery countries' central banks had €297 billion in net liabilities to the Eurosystem (comprising the European Central Bank and the national central banks of the countries whose currency is the euro), roughly double the figure at the end of $2009 . .^{5}$ (See the appendix for a fuller discussion of Eurosystem imbalances.) Together, asset sales and official assistance have worked to ease the immediate adjustment burden for periphery countries, but the future prospect is for a further decline in external borrowing.

\section{The Saving-Investment Mix}

Whether a current account deficit develops because of higher investment or reduced saving matters for assessing risks to growth and financial stability. Foreign borrowing to finance productive investment projects raises national income and should result in a surplus over debt service costs. Foreign borrowing undertaken because of lower levels of saving, in contrast, supports current consumption while building up a debt burden on future income. The composition of investment can also matter. For example, foreign borrowing to finance investment in nontradable sectors such as housing generates no foreign income stream to support repayment.

The saving-investment mix in the euro area periphery countries was not healthy from a growth and stability perspective in

\footnotetext{
${ }^{4}$ As an accounting identity, a country's current account balance is also equal to the gap between outbound and inbound foreign investment. Thus, the 2007 shortfall of $€ 119$ billion in periphery country foreign investment relative to private financial inflows (€219 billion less $€ 338$ billion) is roughly equal to the four countries' combined current account deficit, separated only by official inflows (minor at the time) and statistical reporting errors.

${ }^{5}$ A discussion of central bank cross-border claims within the Eurosystem can be found on page 34 of the Deutsche Bundesbank's Monthly Report for March 2011.
}

Chart 4

\section{Domestic Saving as a Share of GDP}

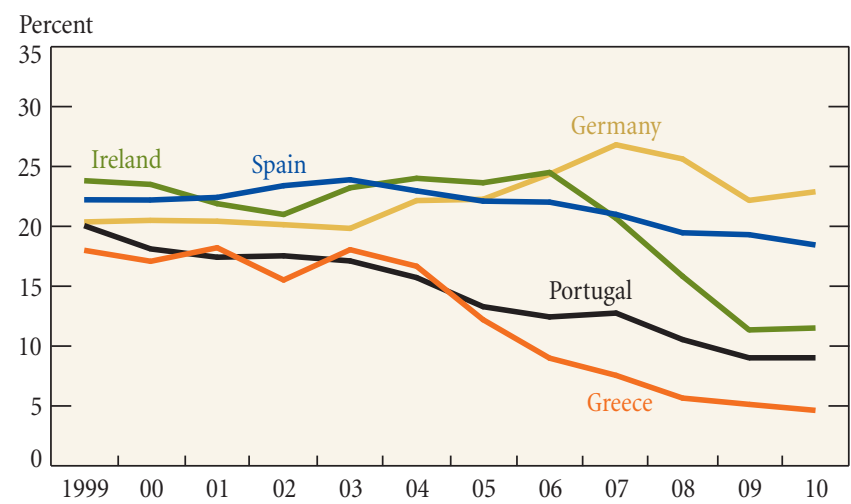

Sources: Eurostat; Haver Analytics.

Note: Domestic saving is measured as the sum of investment spending and the current account balance.

the period leading up to the global financial crisis. Consider first developments on the saving side. Greece and Portugal saw large drops in domestic saving (Chart 4). In Greece, saving fell to just 8 percent of GDP in 2007; in Portugal, it fell to just 13 percent. More detailed national accounts data from the OECD show that Greece's decline in saving is mostly attributable to lower private saving but also to larger government budget deficits. ${ }^{6}$ The decline in Portugal is entirely attributable to lower private saving. Spain shows a modest decline in its saving rate up to 2007, with lower private saving outweighing the impact of improved government fiscal balances leading up to the recession. Ireland displays a relatively stable saving rate through 2007, with little change on either the private or the government side. Germany, in contrast, saw a marked increase in its saving rate, from 20 percent of GDP in 1999 to 26 percent by 2007, mostly driven by higher private saving.

The divergence in saving trends is mirrored in consumption trends, as euro area periphery households responded to lower interest rates by borrowing and spending. Irish real consumption spending increased roughly 55 percent from 1999 to 2007. In Greece and Spain, the comparable figure was roughly 35 percent (Chart 5). Again, Germany stands at the other extreme. Consumption remained essentially flat after 2001, leaving the country with ample funds to lend abroad. Similarly, household liabilities ballooned in the periphery countries, far outpacing growth in disposable income, while liabilities declined relative to disposable income in Germany (see table). These divergent consumer spending trends were a key driver of euro area imbalances.

\footnotetext{
${ }^{6}$ As an accounting identity, a higher government budget deficit implies lower national saving unless it is used to fund higher government investment spending. Changes in government investment spending were minor in the euro area periphery countries leading up to the crisis.
} 
Chart 5

\section{Private Real Consumption Spending}

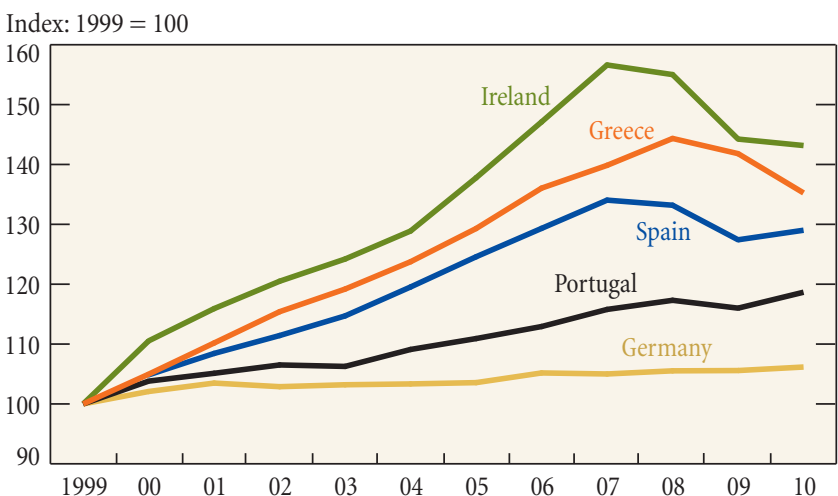

Sources: Eurostat; Haver Analytics.

\section{Euro Area Household Debt Ratios}

Percentage of Disposable Income

\begin{tabular}{lrrc} 
& 1999 & 2007 & Change \\
\hline Greece $^{\text {a }}$ & 26 & 75 & 49 \\
Ireland $^{\mathbf{b}}$ & 113 & 205 & 93 \\
Portugal & 95 & 143 & 48 \\
Spain & 66 & 118 & 52 \\
Germany & 107 & 95 & -12
\end{tabular}

Memo:

United States

88

33

Sources: Eurostat; Haver Analytics; Board of Governors of the Federal Reserve System.

Note: To ensure comparability across countries, we measure disposable income gross of capital consumption.

a First year is 2000 .

b First year is 2001 .

Now consider developments on the investment side. Investment spending as a share of GDP declined slightly in Greece leading up to the crisis, while the investment share in Portugal was flat (Chart 6). In contrast, investment spending as a share of GDP saw a marked rise in Spain and Ireland. But higher investment shares here are explained by booms in residential construction - both countries saw enormous housing bubblesrather than spending on business plants and equipment.

In sum, heavy foreign borrowing reflected low saving rates in Greece and Portugal, while in Spain and Ireland it was used to fuel a housing boom. But the outcome for all four countries was the same: they accumulated foreign debt, but did not use these funds to build up the higher productive capacity that would enable them to repay or service the debt.

\section{Investment Spending as a Share of GDP}

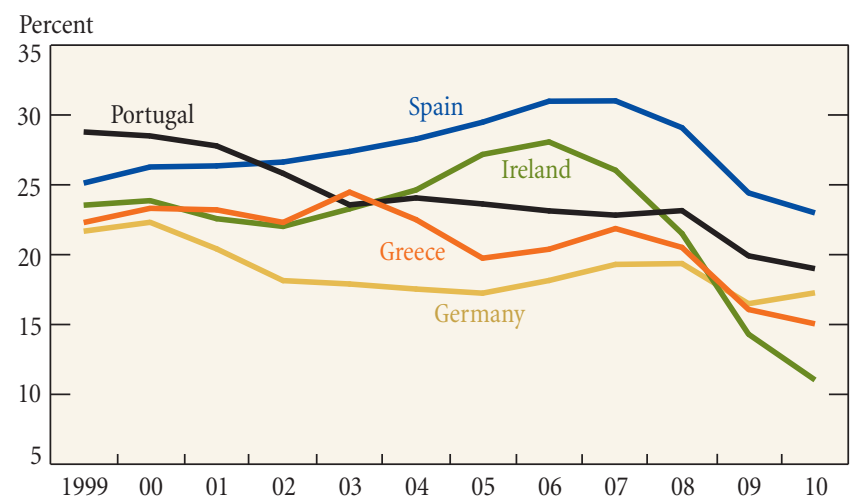

Sources: Eurostat; Haver Analytics.

Competitiveness

It is also instructive to examine foreign borrowing from a competitiveness perspective, that is, a country's performance in external markets. In this connection, recall that a country's saving balance equals its current account balance- the broadest measure of the trade balance. This highlights the fact that improved performance in external markets through higher exports is an avenue to reducing foreign borrowing.

One measure of competitiveness is based on relative unit labor costs in manufacturing. This measure combines three factors that drive competitiveness: wages, labor productivity, and the exchange rate. (Other factors affecting competitiveness, such as quality and product mix, are more difficult to quantify.) The intuition is simple: Higher wages, if not offset by labor productivity gains, erode competitiveness. A stronger exchange rate also erodes competitiveness by raising domestic labor costs when translated into trading partner currencies.

By this measure, Greece and Portugal have suffered a substantial loss in competitiveness in recent years, with unit labor costs rising about 15 percent compared with those of Germany (Chart 7). Spain experienced an even larger comparative loss in competitiveness, with unit labor costs rising 35 percent compared with Germany. Ireland stands out from other periphery countries by roughly matching Germany's competitiveness.

A second measure of competitiveness compares a country's export growth with its trading partners' import growth. Again, the intuition is simple: A country for which export growth lags behind its partners' import growth is losing market share. OECD calculations show that Greece, Portugal, and Spain suffered a substantial drop in competitiveness after the euro area was formed (Chart 8). Greece's exports, for example, are now roughly 25 percent lower than they would have been if its export market 
Chart 7

\section{Relative Unit Labor Costs in Manufacturing}

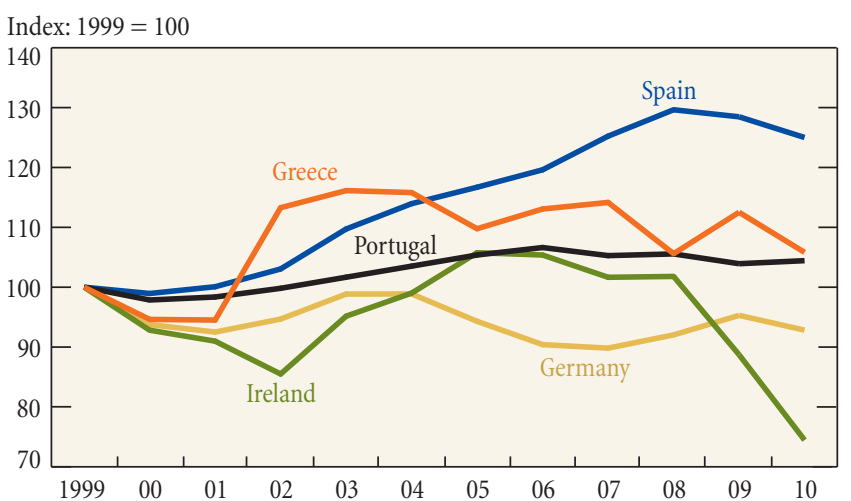

Source: Organisation for Economic Co-operation and Development.

share had held steady. Of note, market shares for Spain and Portugal have stabilized recently, suggesting that competitiveness is no longer eroding in these two countries. Again, Ireland's stronger competitiveness stands out.

These two competitiveness measures are closely connected. Simple regression estimates show that higher relative unit labor costs are strongly associated with lower export volumes and thus lower export market shares (see box). ${ }^{7}$ The estimated relationship is quantitatively and statistically significant for most of the twenty-eight OECD countries in our sample, including the four euro area periphery countries. According to the model results, exports in Greece and Spain are now almost 20 percent lower, and exports in Portugal more than 10 percent lower, than they would have been if unit labor costs had held steady. Since relative labor costs held essentially steady in Ireland over the period, the estimated impact on export market share there is negligible.

Similar results hold when we estimate a model relating export volumes to a third competiveness measure: exchange rates adjusted for relative consumer price inflation rather than relative unit labor costs in manufacturing. (Both adjusted exchange rate series are examples of what economists call real exchange rate indexes.) Again, there is a quantitatively and statistically significant inverse relationship between real exchange rate strength and export performance for most countries in the sample, including the four euro area periphery countries.

It might seem natural to think that the real exchange rate, based on the consumer price index, would have a much weaker connection with export performance, given that the index includes

\footnotetext{
${ }^{7}$ The regression amounts to a standard trade model specification, with growth in export volumes treated as a function of changes in relative prices and foreign demand growth. However, because the dependent variable measures export volumes relative to foreign demand, the demand effects are canceled out in variable construction.
}

Chart 8

\section{Export Market Share}

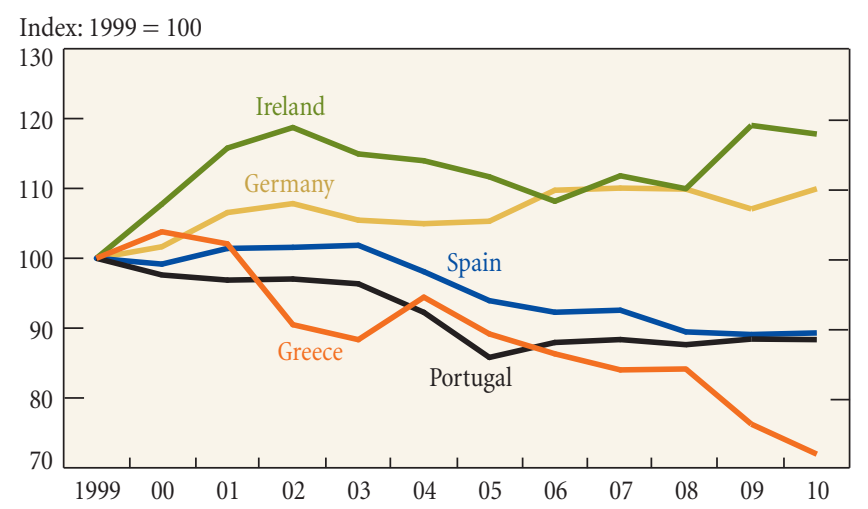

Source: Organisation for Economic Co-operation and Development.

services and other items not sold abroad. However, this measure captures the tendency for consumption and construction booms to bid up domestic wages and draw resources away from the export- and import-competing sectors. In this connection, Ireland had the greatest appreciation among periphery countries over the 1999-2007 period at 22 percent. For Ireland, a domestic demand boom led to sizable current account deficits despite the country's continued success in external markets.

The discussion above is not meant to suggest that independent currencies would provide the euro area periphery countries with a painless adjustment tool. A weaker exchange rate reduces living standards by raising the domestic currency cost of imported consumption goods. It also raises the domestic currency value of debts denominated in foreign currencies. In some cases, through this balance sheet channel, a weaker currency can be contractionary. Nor would conditions heading into the crisis have been the same absent membership in the euro area. In one direction, a negative market reaction to any run-up in external debt might have set in earlier, leaving periphery countries less overextended. In the other direction, capital flight and the attendant market dislocations might have been still more intense if investors had to price in the risk of a unilateral currency adjustment. And absent euro area membership by the countries, a higher fraction of their external liabilities would be in foreign currencies and vulnerable to being scaled up by currency translation effects. Until the adjustment process plays out, it will be difficult to access whether the benefits of joining the euro area have outweighed the costs.

\section{The Adjustment Outlook}

Reduced foreign borrowing in the euro area periphery countries will require higher domestic saving relative to domestic investment spending. From a trade perspective, it will require higher exports relative to imports. The saving-investment and trade perspectives are, in effect, equivalent, linked via national income accounting identities. Yet a consideration of the two perspectives 


\section{Export Performance in OECD Countries}

\section{Model 1: Competitiveness Measured by Relative Unit Labor Costs}

Median estimation results for twenty-eight OECD countries:

Export volume growth $=-0.34 \times($ relative unit labor cost growth $)+0.85 \times($ export market growth $)$

Median value of $\overline{R^{2}}=.61$. Absolute values of median $t$-statistics are in parentheses. The estimated coefficient and test statistic for relative unit labor cost refers to the sum of the current value of the variable and its first lag. Our sample period is 1970-2009 (annual data).

Significance levels for relative labor costs:

1 percent: Australia, Canada, Czech Republic, Finland, France, Germany, Greece, Hungary, Italy, Japan, New Zealand, Poland, Portugal, Spain, Sweden, Switzerland, United States

5 percent: Ireland, Netherlands, Turkey, United Kingdom

10 percent: Belgium, Denmark

Not significant: Austria, Korea, Mexico, Norway

\section{Model 2: Competitiveness Measured by Relative Consumer Prices}

Median estimation results for twenty-eight OECD countries:

Export volume growth $=-0.55 \times$ (relative consumer price growth $)+0.86 \times($ export market growth $)$

Median value of $\overline{R^{2}}=.59$. Absolute values of median $t$-statistics are in parentheses. The estimated coefficient and test statistic for relative consumer prices refers to the sum of the current value of the variable and its first lag. Our sample period is 1970-2009 (annual data).

Significance levels for relative consumer prices:

1 percent: Australia, Canada, Czech Republic, Finland, France, Germany, Greece, Hungary, Ireland, Italy, Netherlands, New Zealand, Poland, Portugal, Spain, Sweden, Switzerland, United States

5 percent: Belgium, Denmark, Japan, Turkey, United Kingdom

10 percent: Austria, Korea

Not significant: Mexico, Norway, Slovakia

side by side sheds light on the challenges associated with different adjustment policies.

One set of adjustment policies focuses on raising national saving through fiscal austerity measures. Needless to say, cutbacks in government spending or hikes in taxes lower current economic welfare. The advantage of fiscal policy is that tightening measures are simple to identify, even if painful to implement, and hold the promise of working relatively quickly. One risk, however, is that austerity measures prove self-defeating by choking off growth and undermining the economy's tax base.

As already described, euro area periphery governments have been taking strong actions on the fiscal front, with fiscal balances this year expected to run several percentage points below their 2009 peaks. Economic performance, however, was poor, with growth averaging -1.1 percent for the group in 2010, compared with 2.1 percent for the rest of the euro area (on an unweighted basis). Whether growth can return as fiscal consolidation continues - and whether political support for consolidation will hold up if growth does not return-remain open questions.
An International Monetary Fund (2010) study examines growth performance during periods of fiscal consolidation in fifteen advanced economies over the last thirty years. ${ }^{8}$ (Significant consolidation efforts took place in a total of 173 countryyear observations.) According to the study, each 1 percentage point in fiscal consolidation relative to GDP subtracts roughly 0.5 percentage point from GDP growth. (Note that the euro area periphery countries are committed to a further reduction in deficits of 6 to 9 basis points relative to GDP from 2010 levels.) Significantly, a systematic tendency for currencies to weaken while fiscal consolidation is under way limits the typical hit to growth. Without a currency adjustment, then, each 1 percentage point in fiscal consolidation relative to GDP subtracts a full percentage point from growth. This finding underscores the challenges now facing periphery countries in reigniting growth.

\footnotetext{
${ }^{8}$ Other studies find a smaller drag on growth from fiscal consolidation and, notably, little systematic role for currency weakness as an offsetting adjustment mechanism (see, for example, Barrios, Langedijk, and Pench [2010]). However, the IMF study argues persuasively that previous work defines fiscal consolidation in a way that conflates success in consolidation with favorable growth outcomes.
} 
Private sector behavior will also play an important role in the future evolution of periphery countries' saving-investment balances. Household saving rates typically rise during downturns, with consumers turning cautious amid increased uncertainty. And indeed, household saving rates rose over the 2007-10 period in twenty of twenty-five OECD countries, including substantial increases in Ireland and Spain, the two periphery countries for which we have data. Business saving rates, in contrast, typically fall, reflecting weakness in corporate profits during downturns. However, business investment typically falls at least as sharply, so that the private saving-investment balance improves and thereby reduces external borrowing. And, indeed, business investment other than housing fell by some 25 percent in real terms over the 2007-10 period. The rub, of course, is that lower business investment is the least attractive way of responding to reduced foreign financing, given the link between business investment and future productivity.

A second set of adjustment measures focuses on raising exports through improved competitiveness. Stronger export growth means that funds once borrowed from abroad could be replaced, at least in part, with higher export revenues. The most straightforward means of improving competitiveness is through a weaker exchange rate, to make domestically produced goods cheaper in foreign currency terms. That option is not available for the periphery countries, due to their membership in a monetary union. Instead, price competitiveness gains must come via a mix of superior productivity gains or wage and price restraints. Given the challenges of boosting productivity and the stickiness of wages and prices, only gradual progress is likely.

Stronger productivity growth represents the most attractive avenue for improving competitiveness, and euro area periphery governments are making moves in this direction. In Greece, for example, efforts have been made to ease regulations that restrict entry of firms into new markets and limit labor mobility. The Greek government has also committed to privatize a number of state-owned businesses, to both boost efficiency and raise revenues. In Spain, the government has recently adopted legislation making it easier for firms to opt out of regional and sectoral labor market agreements mandating high wages and severance costs. How strongly and quickly labor and product market reforms will flow through into improved external competitiveness, however, remains an open question.

The latest data offer some grounds for optimism. The European Commission constructs a competitiveness index based on relative unit labor costs in manufacturing similar to the one in Chart 7, but measured against other euro area members rather than all trading partners. ${ }^{9}$ As of fourth-quarter 2010, Greece and Ireland had made significant gains in competitiveness from 2007

${ }^{9}$ The competitiveness data can be found at http://ec.europa.eu/economy_finance/ db_indicators/competitiveness/data_section_en.htm. compared with other euro area members, at 8.4 and 9.1 percent, respectively. Spain and Portugal had achieved smaller gains, at 3.7 and 1.3 percent, respectively. A look at the drivers of unit labor costs reveals dramatic labor productivity gains in Greece and Ireland and modest gains in Spain and Portugal. (Productivity is measured as real value added per hour worked.) Germany, in contrast, has seen a substantial outright decline in productivity.

These productivity movements reflect differences in the labor market response to the recent downturn. Cutbacks in manufacturing hours worked in the euro area periphery countries have been especially sharp, despite declines in output no larger than elsewhere in the euro area. (Ireland has in fact seen a sizable production gain from 2007.) The cutback in labor inputs in Germany, by comparison, has been especially modest, despite a drop in output larger than the euro area average. Firms in the periphery countries may be making a virtue out of necessity, responding to weaker demand by reorganizing the production process. Again, it is too early to judge whether these short-term adjustments in the euro area periphery countries augur an improved productivity trend. The challenge going forward will be to ensure that productivity gains come from innovation and business reorganization, and not merely from shedding workers. In the best case, productivity-driven gains in foreign market share would leave the export sector as an important source of employment growth. Similarly, productivity gains in importcompeting industries could support employment by shifting demand from goods and services purchased from abroad to goods and services produced by workers at home.

The scale of the adjustment challenge in the periphery countries will be in part determined by the pace of growth in export markets. Domestic incomes can rise relative to domestic demand even without improved competitiveness given a favorable external environment. For example, Greece's real exports rose by some 44 percent over the 1999-2007 period even as the country suffered major losses in export market share. An increase in external demand would materially ease the periphery countries' adjustment burden.

Adjustment in the periphery countries would also occur more smoothly and with a reduced drag on living standards given a reduction in Germany's saving surplus through higher domestic consumption. This would allow the periphery countries to boost export income even if they made only limited progress improving competitiveness. Indeed, British economist John Maynard Keynes argued decades ago that a fixed exchange rate system could only function effectively over the long run if there were mechanisms in place to promote adjustment in countries with surpluses as well as those with deficits. ${ }^{10}$ The difficulties the euro area now faces adjusting to external imbalances raise the question whether new

\footnotetext{
${ }^{10}$ See the discussion by Skidelsky and Joshi (2010).
} 
institutional arrangements should be considered to induce earlier and more automatic rebalancing. ${ }^{11}$

\section{Conclusion}

There were large saving imbalances among euro area countries in the years leading up to the recent sovereign debt crisis. The crisis was sparked by a loss of confidence by private investors in periphery countries' government debt, causing a spike in domestic interest rates. As a result, periphery countries will likely have to go forward with greatly reduced borrowing from foreign investors. The borrowed funds had supported higher spending

\footnotetext{
${ }^{11}$ Goodhart and Tsomocos (2010) propose a tax on capital outflows within the euro area to act as a brake on the buildup of external imbalances and to ensure that the adjustment burden is shared among countries with surpluses and deficits. Giavazzi and Spaventa (2010) argue for strengthened financial regulation at the European Union level to act as a brake on the domestic credit booms often fueled by heavy foreign borrowing.
}

at a relatively low cost. Now, a difficult adjustment to the loss of cheap foreign financing is under way.

The adjustment process highlights the dangers of large imbalances in a monetary union. With an independent national currency, policymakers can turn to depreciation or devaluation to engineer quick gains in competitiveness, replacing foreign borrowing — at least in part—with higher export revenues. How painful the adjustment process for periphery countries will prove depends on how quickly these countries boost their competitiveness in export- and import-competing industries, and on the pace of demand growth in the euro area core countries and in the rest of the world. The evidence to date has been mixed, with overall growth still weak but with some early gains in labor productivity. The downside risk is that failure to achieve sustained productivity gains would leave adjustment to occur only through lower wages and slower growth in domestic consumption and investment spending. 


\section{Appendix: Eurosystem Imbalances}

The Eurosystem, which comprises national central banks in the euro area and the ECB, is currently managing large imbalances among its central banks. The euro area's common payments system facilitates the movement of bank reserves across countries as the counterpart to cross-border commercial bank transactions. For example, when a Greek resident writes a check to a German company to make a purchase, the check is cleared through a transfer of reserves from the Greek commercial bank to the German bank. The transfer occurs by means of national central bank transactions within the Eurosystem, with the Bundesbank acquiring a claim on the Eurosystem and the central bank in Greece incurring an equal liability.

Prior to the ongoing debt crisis, reserve outflows and inflows involving commercial banks in Greece, Ireland, Portugal, and Spain roughly balanced, with a payments deficit on transactions in goods and services, represented by their current account deficits, offset by a surplus of foreign investment flows into these countries (Chart A1). Recently, however, private investors elsewhere in the euro area have been liquidating rather than adding to claims on these countries. As a result, central banks in the four periphery countries had built up some $€ 311$ billion in net liabilities to the rest of the Eurosystem as of first-quarter 2011. Commercial banks in the periphery have moved to offset the lost reserves by increasing borrowing from their national central banks. In particular, through refinancing operations, commercial banks can receive new reserve money by posting eligible securities as collateral. Without this lifeline, commercial banks in the periphery would be forced to shrink in line with the cross-border loss of bank reserves.

The outflow could have gone to any core euro area country, but thus far, bank reserves have gone mainly to Germany, with

\section{Chart A1 \\ Net Claims on the Eurosystem by the Periphery Countries}

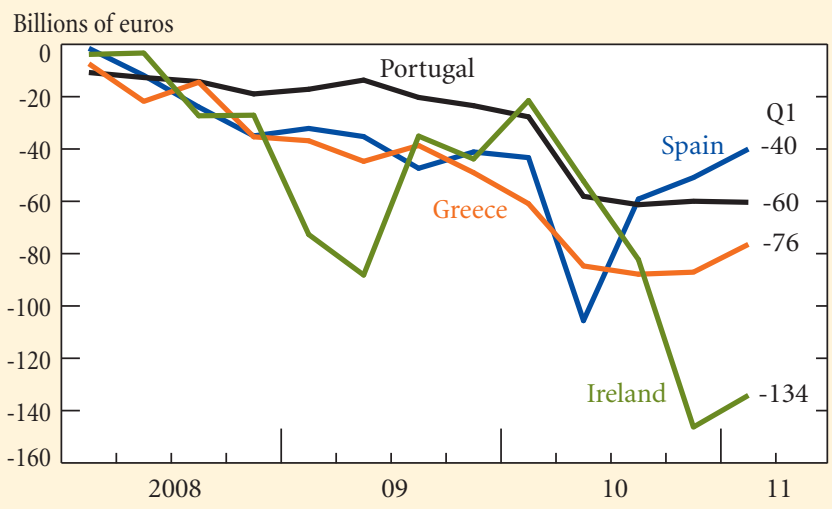

Sources: International Monetary Fund; Haver Analytics. the Bundesbank holding €323 billion in net claims on the rest of the Eurosystem as of the first quarter (Chart A2). German banks have offset the inflow of surplus reserves by reducing their borrowings from the Bundesbank.

The risk to the Eurosystem from cross-border imbalances depends on the quality of the collateral posted in refinancing operations. In accordance with Eurosystem rules, central banks book collateral at current market value, with local commercial banks subject to margin calls to offset any loss in value. In addition, substantial haircuts are applied to lower rated securities. Any losses would be shared by the Eurosystem as a whole rather than by creditor central banks. The Bundesbank, for example, would bear roughly 27 percent of any losses, in line with its share in the Eurosystem. A key exception concerns commercial bank reserves created in Ireland through the Emergency Liquidity Assistance program. The credit risk for the estimated $€ 54$ billion outstanding under the program rests with Ireland's central bank.

Eurosystem credit to periphery banking systems has helped to make ongoing current account deficits in those countries easier to finance. There is no direct correspondence between payments imbalances in the Eurosystem and countries' current account balances since the payments balance also depends on financial transactions. Even so, absent Eurosystem credit, periphery countries would have needed to attract an offsetting increase in other inflows (or an offsetting reduction in capital flight), likely through still higher interest rates. The alternative would have been a sharper compression in domestic demand to force current account deficits to shrink more rapidly than has been the case thus far.

\section{Chart A2 \\ Net Claims on the Eurosystem by Germany and the Periphery Country Group}

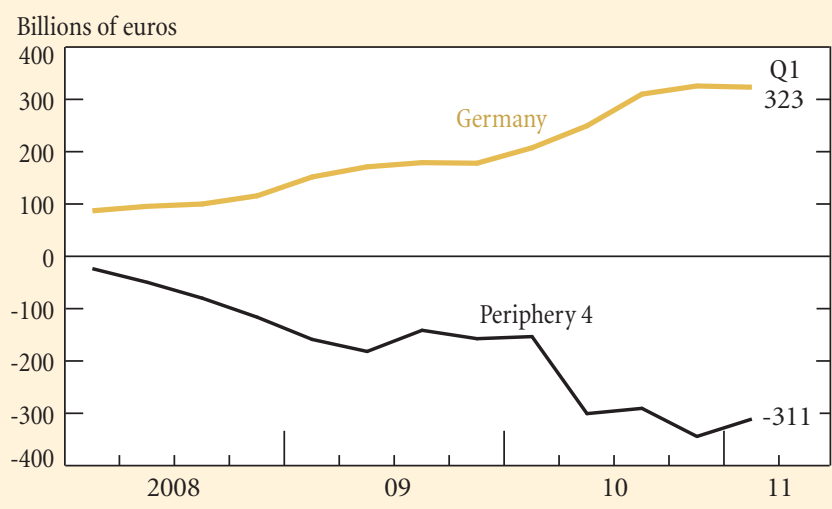

Sources: International Monetary Fund; Haver Analytics. 


\section{References}

Attanasio, Orazio P., and Guglielmo Weber. 2010. "Consumption and Saving: Models of Intertemporal Allocation and Their Implications for Public Policy." NBER Working Paper no. 15756, February.

Barrios, Salvador, Sven Langedijk, and Lucio Pench. 2010. "EU Fiscal Consolidation after the Financial Crisis: Lessons from Past Experiences." European Commission European Economy Economic Papers, no. 418, July.

Deutsche Bundesbank. 2011. “The Dynamics of the Bundesbank's TARGET2 Balance." Monthly Report 63, no. 3 (March): 34-5. Available at http://www .bundesbank.de/download/volkswirtschaft/monatsberichte/2011/ 201103mb_en.pdf.

European Commission. 2010. "Public Finances in EMU 2010.” European Economy 4. Available at http://ec.europa.eu/economy_finance/publications/ european_economy/2010/pdf/ee-2010-4_en.pdf.
Giavazzi, Francesco, and Luigi Spaventa. 2010. "The European Commission's Proposals: Empty and Useless." Vox, October 14. Available at http://www .voxeu.org/index.php?q=node $/ 5680$.

Goodhart, Charles, and Dimitrios Tsomocos. 2010. Eurointelligence, September 24. Available at http://www.eurointelligence.com/index.php?id=581\&tx_ttnews\%5btt _news\%5d=2903\&tx_ttnews\%5bbackPid\%5d=901\&cHash $=1 \mathrm{e} 554 \mathrm{e} 1611$.

International Monetary Fund. 2010. "Will It Hurt? Macroeconomic Effects of Fiscal Consolidation.” World Economic Outlook, October: 93-124. Available at http://www.imf.org/external/pubs/ft/weo/2010/02/pdf/c3.pdf.

Skidelsky, Robert, and Vijay Joshi. 2010."Keynes, Global Imbalances, and International Monetary Reform, Today." Blog post, June 23. Available at http:// www.skidelskyr.com/site/article/keynes-global-imbalances-and-international -monetary-reform-today/.

\section{ABOUT THE AUTHORS}

Matthew Higgins is a vice president in the Emerging Markets and International Affairs Group of the Federal Reserve Bank of New York; Thomas Klitgaard is a vice president in the Research and Statistics Group.

Current Issues in Economics and Finance is published by the Research and Statistics Group of the Federal Reserve Bank of New York. Linda Goldberg, Erica L. Groshen, and Thomas Klitgaard are the editors.

Editorial Staff: Valerie LaPorte, Mike De Mott, Michelle Bailer, Karen Carter

Production: Carol Perlmutter, David Rosenberg, Jane Urry

Subscriptions to Current Issues are free. Send an e-mail to Research.Publications@ny.frb.org or write to the Publications Function, Federal Reserve Bank of New York, 33 Liberty Street, New York, N.Y. 10045-0001. Back issues of Current Issues are available at http://www.newyorkfed.org/research/current_issues/.

The views expressed in this article are those of the authors and do not necessarily reflect the position of the Federal Reserve Bank of New York or the Federal Reserve System.

\section{Check Out Our Blog: Liberty Street Economics}

Readers looking for timely and frequent posts on a range of topics will enjoy Liberty Street Economics. The blog presents new research by our large staff of economists, with a less technical style that makes their insights accessible to a wide audience.

Liberty Street Economics also publishes reader comments and author responses, with the goal of broadening our dialogue with you.

Recent posts include:

- “Would a Stronger Renminbi Narrow the U.S.-China Trade Imbalance?" Matthew Higgins and Thomas Klitgaard

• “The Vanishing U.S.-E.U. Employment Gap," Christian Grisse, Thomas Klitgaard, and Ayşegül Şahin

- “Is There Stigma to Discount Window Borrowing?" Olivier Armantier, Eric Ghysels, Asani Sarkar, and Jeffrey Shrader

- “Helping Unemployed Borrowers Meet Their Mortgage Payments, James Orr and Joseph Tracy

- "Consumer Goods from China Are Getting More Expensive," Mary Amiti and Mark Choi

So be sure to visit our blog—we welcome your comments!

$$
\text { libertystreeteconomics.newyorkfed.org }
$$

